Journal of

Contemporary History

\title{
Nuclear Power for a Dictatorship: State and Business involvement in the Spanish Atomic Program 1950-1985
}

\begin{tabular}{|r|l|}
\hline Journal: & Journal of Contemporary History \\
\hline Manuscript ID: & JCH-Nov-2014-0849.R1 \\
\hline Manuscript Type: & Article \\
\hline Keywords: & $\begin{array}{l}\text { nuclear energy, economic history, energy policy, electricity sector, Spain, } \\
\text { dictatorship }\end{array}$ \\
\hline Abstract: & $\begin{array}{l}\text { Spain was the first developing country to commercially exploit a nuclear } \\
\text { power plant. By the early 1970s Spain become the major nuclear client of } \\
\text { the US, the world's largest reactor exporter. Despite its importance, } \\
\text { historians are just beginning to revisit and establish the sequence of the } \\
\text { events that make up Spain's nuclear history. This paper analyses the role } \\
\text { played by the State in enabling one of Western Europe's poorest countries } \\
\text { to join the exclusive nuclear power club. In a departure from the } \\
\text { technological approach used in previous literature, the history of Spain's } \\
\text { progress in the nuclear power field is retraced against the background of } \\
\text { its political and economic evolution. }\end{array}$ \\
\hline
\end{tabular}




\section{Nuclear Power for a Dictatorship: State and Business Involvement in the Spanish Atomic Program 1950-1985}

\section{Introduction}

Spain was one of the poorest countries in Western Europe in 1950, but 20 years later, it had successfully connected its first three nuclear power plants to the grid. By the early 1980s, Spain had eight nuclear reactors producing electricity commercially and was discussing highly ambitious medium- and long-term plans to build more. How was this possible in a backward economy on the periphery of Europe? This paper summarizes and explains Spain's nuclear power history as the consequence of the state's endeavor to address the complex technological challenges involved in its the development and implementation.

Institutionally speaking, this undertaking commenced under a dictatorship and the economic and industrial circumstances were far from favorable. Spain had only recently emerged from the post-civil war autarchy of the 1940s and still had one of Europe's lowest GDPs per capita, together with dire energy shortages and a dearth of physical, financial, and human capital. One of the key explanations for the phenomenon lies in the international Cold War context in which the events took place. The US "Atoms for Peace" plan and the Madrid bilateral military agreements, both dating to 1953 , were the first defining steps of both Spain's military and civil nuclear strategy.

By 1971, and despite the economic spur of the Golden Age, Spain ranked much higher in the world for nuclear power generation than it did for economic development. Table 1 shows some comparative indicators of installed nuclear power in relation to population and wealth for that year. They show Spain to be the poorest country, and the only dictatorship, in the 
Western world to be commercially producing nuclear energy. ${ }^{1}$ Capitalist Europe led the world in this respect, ahead of both atomic energy pioneers, the US and Canada, together. While in terms of nuclear power per million inhabitants Spain was behind Europe or North America, it was close to Japan and ahead of Italy or Sweden. In terms of the ratio of nuclear power to GDP, Spain ranked higher, however - above West Germany, Japan and Italy and not far behind the US and Switzerland. In other words, Spain's nuclear effort was on a par with that of some of the most highly developed economies in the world. Despite having a much lower income per capita, Spain's progress in the nuclear power field was comparable with that of highly industrialized countries. A priori, Spain would classify as a successful "early comer". In the middle of its own process of economic modernization and industrialization, Spain had quickly and successfully tapped into a new, technologically complex energy source involving high capital costs and strict institutional controls. Government support was decisive in this process.

[Table 1: World figures for atomic energy production and nuclear intensity, 1971]

Despite its importance, work on the economic historiography of nuclear energy has barely gotten underway. Some country-specific histories have begun to appear, but few global-scale comparative studies have been attempted. ${ }^{2}$ This does not imply a complete lack of published

\footnotetext{
${ }^{1}$ Other countries under dictatorial rule starting nuclear programs coming after the Spanish example, such as South Korea or Turkey, had periods of civil rule in between, see S. Choi, et alt, 'Fourteen lessons learned from the successful nuclear power program of the Republic of Korea', Energy Policy, 37 (2009) pp. 5494-5508; S.M. Sirin, ‘An assessment of Turkey's nuclear policy in light of South Korea's nuclear experience', Energy Policy, 38 (2010) pp. 6145-6152. Other non-democratic nations such Argentina or Yugoslavia had yet to make their nuclear plans while Spain had is first reactor already plugged to the network.

2 For country specific histories see B. Balog, Chain Reaction: Expert Debate and Public Participation in American Commercial Nuclear Power, $1945-1975$ (New York 1991); G. Hecht, The Radiance of France. Nuclear Power and National Identity after World War II (MIT, MA 1998); J. Radkau and L.Hahn, Aufstieg Und Fall der Deutschen Atomwirtschaft. (Oekom-Verlag, Berlin. 2013). D. Fischer, History of the International Atomic Energy Agency. The First Forty Years (IAEA, Vienna 1997); M. Jasper, Die Finanzierung der Stilllegung von Kernkraftwerken: Eine Studie aus der Perspektive des deutschen und europäischen Wirtschaftsrechts (Baden-Baden 2008).
} 
research on the history of nuclear programs, however. There exists some literature on the history of the Spanish nuclear program as such, as well as contemporary works influenced by the period in which they were written and by the nuclear debate that lingers in the Western world. ${ }^{3}$ Internationally, the risk of nuclear proliferation has meant that most works on the subject are more geopolitically than economically biased. ${ }^{4}$

In Spain, as in most countries, technology historians pioneered the recording of nuclear history. Their main contributions have been in the study of technology transfer, institutional scientific research and development networks, and nuclear applications in medicine and industry. ${ }^{5}$

${ }^{3}$ On the history of the Spanish nuclear program see R. Caro (ed), Historia nuclear española, (Madrid: 1995); A. Alonso Santos, 'Requisitos básicos para incrementar los activos nucleares en España'. Dyna; 82, 9 (2007), 462470. For contemporary writing as the nuclear project unfolds see J. Muñoz and A. Serrano, 'La configuración del sector eléctrico y el negocio de la construcción de centrales nucleares', Cuadernos de Ruedo Ibérico, (1979), 6366; Beyond Spain, see W. Wood, Insuring Nuclear Power: Liability, Safety an Economic Efficiency. (JAI Press, Greenwich \& London 1982); A. M., Weinberg, et al., The Second Nuclear Era: a New Start for Nuclear Power (Praeger, New York 1985); J.L. Campbell, Collapse of an Industry: Nuclear Power and the Contradictions of US Policy (Cornell University Press, New York, 1988); S.D. Thomas, The Realities of Nuclear Power: International Economic and Regulatory experience, (Cambridge, MA 1988); S. Cohn,. 'The Political Economy of Nuclear Power (1945-1990): The Rise and Fall of an Official Technology', Journal of Economics Issues, XXIV, 3, (1990) 781-811.

${ }^{4}$ E. Solingen (ed), Sanctions, Statecraft, and Nuclear Proliferation, (Cambridge, MA 2012).

${ }^{5}$ On the study of technology transfer, see A. Presas i Puig, 'On a speech by Jose Maria Albareda given before Germany's academic authorities: a historical note', Arbor-Ciencia Pensamiento y Cultura, 160, no. 631-32 (1998) 343-357; A. Presas i Puig, 'The correspondence between Jose Maria Otero Navascues and Karl Wirtz: An episode in the international relations of the Junta de Energia Nuclear'. Arbor-Ciencia Pensamiento y Cultura, 167, no. 659-60 (2000) 527-601; A. Presas i Puig, 'Science on the periphery. The Spanish reception of nuclear energy: An attempt at modernity?' Minerva 43, no. 2 (2005): 197-218. On the institutional scientific research and development network see A. Romero de Pablos, and J. M. Sánchez Ron, Energía nuclear en España. De la JEN al CIEMAT. CIEMAT, (Madrid 2001); A. Romero de Pablos 'The early days of nuclear energy research in Spain: José María Otero Navascues's foreign trip (1949)'. Arbor-ciencia Pensamiento y Cultura, 167, no. 659-60 (2000) 509-525; M. Ordóñez and J.M. Sánchez Ron, 'Nuclear energy in Spain. From Hiroshima to the sixties', in Paul Forman and J.M. Sánchez Ron (eds), National Military Establishment and the advancement of science and technology (Boston 1996) 185-213; J. M. Sánchez Ron, 'International relations in Spanish physics from 1900 to the Cold War', Historical Studies in the Physical and Biological Sciences 33, no. 1, 9, (2002) 3-31. For nuclear applications in medicine, see M. Castell Fàbrega, Historia de la medicina nuclear en España. (Bellaterra. 1992); A.M. Navarro, 'Atoms for Peace... and for Medicine: popularization of the medical applications of nuclear energy in Spain' Revista Española de Medicina Nuclear 26, no. 6 (2007) 385-399; M.J. Santesmases, 'Peace propaganda and biomedical experimentation: Influential uses of radioisotopes in endocrinology and molecular genetics in Spain (1947-1971)' Journal of the History of Biology 39, no. 4 (2006) 
The nuclear program is addressed only indirectly in volumes and articles dealing with the history of the electricity companies that were involved. ${ }^{6}$ The first approaches with an economic focus, however, emerged precisely in historical accounts of the Spanish electricity sector and specific nuclear plants. ${ }^{7}$ Some attempts are just beginning to obtain a fuller, longerterm picture. ${ }^{8}$

A comprehensive historical overview should include the peculiarities of the new institutions and specific nuclear energy laws, technological and economic transfers from abroad, the effects on electricity companies, private and public manufacturing industries, financial issues (taxes, subsidies, and domestic and foreign credit), human capital formation, and an overall cost-benefit analysis of the country's nuclear power plants.

Our review focuses on the role played by the state, without which Spain, like other countries, would have found it impossible to initiate nuclear power production for peaceful purposes. As the story unfolds, we will also need to ponder the private sector's contribution in seeking support from the state, especially that of the utility companies that will ultimately be in charge of building the nuclear plants. Technological periodization focuses on dating the reactors of $1^{\text {st }}, 2^{\text {nd, }}$ and $3^{\text {rd }}$ generation. For Spain, such periods cover pre-1968 for the first one, 1969-

765-794. For industry applications, see F.X. Barca Salom, 'La politica nuclear espanyola: el cas del reactor nuclear Argos', Quaderns D'Historia de L'Enginyeria IV, (2000) 12-44; F.X. Barca Salom, 'Nuclear power for Catalonia: The role of the Official Chamber of Industry of Barcelona, 1953-1962' Minerva 43, no. 2, (2005) 163-181; F.X. Barca Salom, 'Dreams and needs: The applications of isotopes to industry in Spain in the 1960s' Dynamis 29: (2009) 307-336; F.X. Barca Salom, 'Secrecy or Discretion: Transfer of Nuclear Technology to Spain in Franco Period', History of Technology, 30.(2010).

${ }^{6}$ G. Anes and Gómez A. Mendoza, Un siglo de luz : historia empresarial de Iberdrola, (Madrid 2006);

G. Anes, S.Fernández Plasencia and J. Temboury Villarejo, Endesa en su historia (1944-2000), ( Madrid 2001); A. Gómez Mendoza, Electra y el Estado : la intervención pública en la industria eléctrica bajo el franquismo, (Pamplona 2007); J.A. Inchausti et al., "Compañía Sevillana de Electricidad: cien años de historia', (Sevilla 1994).

7 J. Garrués, 'Las estrategias productivas, financieras e institucionales de Iberduero', en G. Anes and Gómez A. Mendoza, Un siglo de luz. Historia empresarial de Iberdrola (Madrid 2006) 497-575; E. Sánchez Sánchez, 'La centrale nucléaire hispano-française de Vandellos: logiques économiques, technologiques et politiques d'une décision', Bulletin d'Histoire de l'Electricité. 36, (2000) 5-30; E. Sánchez Sánchez, Rumbo al Sur. Francia y la España del desarrollo, 1958-1969 (Madrid 2006); E. Sánchez Sánchez, 'The French Armament Firms and the Spanish Market, 1948-1975', Business History, 52/3, (2010) 435-452.

${ }^{8}$ M.d.M, Rubio, 'Nuclear Energy in Spain. A research agenda for economic historians' in, A. Presas (ed) $A$ Comparative Study of European Nuclear Energy Programs, Max Planck Institute for the History of Science, 419 (Berlin, 2011) 71-94. 
1978 for the second one, and after 1979 for the third. ${ }^{9}$ We take a step beyond previous technologically oriented studies by proposing a new historical periodization of nuclear energy development up to the 1983 moratorium, against the background of Spain's political and economic evolution. We base our analysis on unpublished documents from the archives of the Bank of Spain and the US Export-Import Bank, along with legislative and government documents (Spain's Official State Bulletin (BOE), Government Energy Plans, Official Parliamentary Bulletin (BOC), and US NARA achieves), business records (UNESA and the electricity companies), and newspaper archives from Spain's nuclear development era.

We begin precisely with this new historical periodization. The following sections trace the role of the state in three stages: the introduction of measures for the creation of the sector (1948-1962), the construction of the Spanish nuclear network -government, experts, industry(1962-1976), and the response of Spain's first democratic governments to the nuclear legacy left by the dictatorship during the nuclear power boom triggered by the oil crisis (1977-1985). Of these, the last two stages are the most neglected in historical studies and constitute the core and the original contribution of this paper. We close with some conclusions.

\section{The three stages of the Spanish nuclear program}

Given the technological complexity, financial costs, and security risks involved, government action was essential. This was even more important in Spain because the country lacked the scientific and technical foundations for taking up the nuclear energy challenges. The state was responsible for 1) defining the regulatory framework and creating nuclear power agencies, firms and institutions; 2) directly and indirectly funding technology transfers from abroad, the formation of the necessary human and scientific capital, and the testing of atomic know how; 3) guaranteeing supplies of natural and enriched uranium, exploiting the country's uranium

\footnotetext{
${ }^{9}$ Alonso Santos, 'Requisitos básicos para incrementar los activos nucleares en España', p.463.
} 
reserves, and managing radioactive waste; 4) defining national energy plans and 5) promoting an economic and fiscal policy for the development of a domestic sector to produce some of the necessary equipment and components for nuclear power plants, and thus reducing the country's dependence on foreign technology.

From these five state responsibilities, some important facts emerge. First, the nuclear development commitment required a major but still uncalculated amount of public funding. Second, such rapid nuclear development was only possible thanks to collaboration among the world's leading technological nations. Third, this strategy had a clear beneficiary: Spain's private sector (electricity companies, capital goods manufacturers, building and consultant engineering companies, and banks to contribute to the funding), which was to build the nuclear power plants throughout the 1960s and 1970s. In other words, in an emerging economy such as Spain, the state laid down all its resources to build (indirectly) nuclear power plants. This strategy entailed solving technological and logistical problems in both the private and public sectors. Over time, however, the institutional framework was adapted to address changes in the dictatorship's economic policy and, of course, in the international scenario. $^{10}$

The first stage (1948-1962) truly reflected the industrial policy of the 1950s. For the economy as a whole, that implied switching from the autarkic policies of the 1940 s to the new import substitution industrialization (ISI) policies of the 1950s and early 1960s. However, economic policy, like nuclear policy, still took place under the management of military engineers, and strict control by the INI and the army. ${ }^{11}$ In a country with rigid government restrictions on the

\footnotetext{
${ }^{10}$ De la Torre, J. and Rubio, M.d.M., 'El Estado y el desarrollo de la Energía Nuclear en España, C. 1950-1985', Documentos de Trabajo de la Asociación Española de Historia Económica, DT-AEHE N 1403, (2014), p.7.

${ }^{11}$ The National Institute of Industry [INI], founded in 1941, was the holding of public companies, inspired by the IRI of Fascist Italy, where the state acted as an entrepreneur receiving preferential treatment in the allocation of scarce resources (energy, raw materials, imported machinery, currencies) within an autarkic vision of the
} 
entry of foreign capital and technology, the institutional framework made the most of the US decision to open up nuclear energy to the so-called "Free World" and the civil sector. Meanwhile, private companies prepared themselves to exploit potential business opportunities within this tight framework, hoping that their role would increase in the decades ahead. The story of the birth and early development of the Junta de Energía Nuclear [JEN, the Nuclear Energy Board] is a paradigmatic example of this, as will be seen.

During the second stage (1962-1976), the changes in the Spanish regulatory framework for nuclear energy were more than simply an attempt to legislate a sector hitherto barely mentioned in the Official State Bulletin. The government's developmentalist economics shaped industrial policy with a direct impact on the nuclear energy sector. The government's intervention aimed to achieve a form of industrialization that would increase exports of manufactured goods. By opening up opportunities for the private sector and the entry of foreign capital and technology, it called for a more modern, civilian style of management, and a subtle reorientation of the INI. Expectations of economic development fuelled optimism for atomic energy and culminated in the first generation of nuclear power plants. The first oil crisis propelled a nuclear power boom in the final years (1972-1976) of this second stage, accompanied of other external shocks and internal changes.

In the third stage (1977-1985), the nuclear plan of the 1970s eventually decelerated under the burden of economic and institutional uncertainties. With energy prices soaring due to the first oil crisis, the government's commitment to build nuclear power plants was stronger than ever. By the mid-1970s, the political transition from dictatorship to democracy marked the decision-making process, while the public debate on the nuclear issue emerged and the

economy that relegated private enterprise. E. San Román, Ejército e Industria. El nacimiento del INI, (Barcelona 1999); P. Martín Aceña and F. Comín, INI. 50 años de industrialización española (Madrid 1991); A. GómezMendoza, ed., De mitos y milagros. El Instituto Nacional de la Autarquía (1941-1963) (Barcelona 2000). 
economic crisis deepened in parallel to the worsening of international money markets. Franco's last governments and the first democratic ones all attempted to sustain nuclear expansion until misgivings about its economic and financial viability culminated in the 1983 moratorium and the introduction of new regulatory measures. These three stages share one basic feature: the immediate response of the Spanish nuclear network (government, experts and industry) to the dynamics of worldwide events.

\section{The creation of the institutional framework for nuclear power (1948-1962)}

Technology historians have provided us with details about how nuclear knowhow reached Spain in the early stages. Political-military and economic objectives motivated Spain's prompt response to the nuclear challenge. A combination of external and internal factors would alter the scenario. Internationally, the Cold War played its role; nationally, it was the need to restore economic progress. Both forces help to explain why Franco agreed to the transfer of this new technology, along with the rest of the Western world. For Spain, it began with the military treaty of 1953 and the atomic agreement of 1955, both with the US. Over the prior decade, the government had shown strong interest in the potential military uses of the atom. Considering it a delicate matter, the government entrusted it to the army engineers and the secret service. In fact, Spain's first move was to approach the Italian and German scientific establishments. ${ }^{12}$

By 1948, the government had created a specific unit for atom investigation within the Consejo Superior de Investigaciones Científicas [CSIC, the Spanish Scientific Research Council]. Three years later, the CSIC unit would become the main public agency for the control of atomic activity: the JEN. In short, the institutional framework created for the management of

\footnotetext{
${ }^{12}$ Ordóñez and Sánchez-Ron ,'Nuclear energy in Spain'; Presas i Puig, 'Science on the periphery'.
} 
the Spanish nuclear program mostly replicated those being set up in the US, UK, France, Japan, and the Federal Republic of Germany. Spain's capabilities, however, were beset by the dictatorship and a backward economy.

In parallel, access to the country's uranium and radioactive mineral resources was restricted to the state, and exporting it strictly forbidden. ${ }^{13}$ Along the lines of the autarkic principles and the new ISI policy, it made sense for the Spanish authorities to pursue a nuclear reactor that used natural uranium given its existence in the country. A priori, the domestic reserves of natural uranium would be a lever for a reactor relatively more independent from foreign assistance. $^{14}$

The role of government was essential in facilitating the transfer of nuclear knowledge from the leading countries, funding the required investment, and managing the risks involved in domestic and global security (curbing the temptation to manufacture nuclear weapons). ${ }^{15}$ The country lacked the basic scientific and technical knowhow to meet the atomic challenge. At the time, it could only be addressed by the public sector, albeit with high opportunity costs. The government would later involve major private companies in the business opportunities provided by the new power source. September 1953 saw the signing of military and financial agreements between Washington and Madrid (bringing Spain back into the international arena) and only a few months later, in December of that same year, President Eisenhower presented the North American Atoms for Peace Program to the United Nations. This boosted

\footnotetext{
${ }^{13}$ Decree of December 29, 1948 published in Boletín Oficial del Estado [BOE] No 19, (Madrid 1949).

${ }^{14}$ See Chapter 5 in De la Torre and Rubio-Varas, La financiación exterior del desarrollo industrial español a través del IEME, 1950-1982, Estudios de Historia Económica №69, Banco de España (Madrid 2015, in press). For a comparative analysis of the nuclear programs of France, Spain and Italy from the point of view of uranium prospection and against the background of the US policy regarding this fuel, see M. Adamson, L. Camprubi and S. Turchetti, "From the ground up: uranium prospection in Western Europe", in S. Turchetti and P. Roberts The Surveillance Imperative: Geosciences during the Cold Ward and Beyond (New York, NY 2014), pp. 23-44.

${ }^{15}$ Sánchez Sánchez, 'La centrale nucléaire hispano-française de Vandellos'; Sánchez Sánchez, 'The French Armament Firms'; A. Viñas, En las garras del águila. Los pactos con Estados Unidos, de Francisco Franco a Felipe González (1945-1995) (Barcelona 2003).
} 
North American support for Spain's nuclear plan and raised the country to a privileged position among the beneficiaries of the US program. Spain participated from the start as an associate or full member in the main international agencies and forums, seeking the cooperation of the world's leading atomic powers. ${ }^{16}$ This was the government's response to the situation created by the Cold War and the rapid pace of the modernization of Western economies. From the US perspective, active collaboration was strategic: because of its geographic position, Spain was considered the last bastion in Europe against Communism in case of a war in which Soviet forces expanded their control over the remainder of the continent. $^{17}$

From its very founding, the JEN's main responsibility was to undertake the regulation, development, and implementation of civil atomic uses (medicine, agriculture, industry and power) through research programs in all of the auxiliary sciences (physics, chemistry, materials). JEN's Annual Report for year 1961 described its main three objectives: the training of personnel, the search for domestic supplies of nuclear raw materials", and "the honing of new techniques with a view to creating a major national nuclear industry". It acknowledged that "the fundamental and ultimate purpose of nuclear power was to obtain electricity $[\ldots]$ at a price that would compete with that of traditional sources". ${ }^{18}$ Aware of the huge budget that this would require, JEN officials linked the country's nuclear bid to the astronomic 50,000 million pesetas (over $\$ 830$ million) that had already been invested in

${ }^{16}$ Spain waited until 1958 to be admitted to the IMF and the OEEC, but in 1955, it took part in a decisive international nuclear meeting held in Geneva. It joined the IAEA of the UN; the European Nuclear Energy Agency (ENEA); the European Society for Chemical Treatment of Irradiated Fuels (Eurochemic), under the ENEA; the European Atomic Forum (Foratom), established in 1960 by the six member countries of the EEC; and the European Centre for Nuclear Research (ECNR). Spain signed the first bilateral nuclear agreement with the US AEC in 1955, and the second with the French CEA the following year (see Romero de Pablos and Sánchez Ron, Energía nuclear en España and Barca Salom, 'Secrecy or Discretion'). Its nuclear agreement with Canada was signed in 1964 (BOE No 124, 25 May 1965).

${ }^{17}$ The Current Situation in Spain, 11/5/47, Records of the Central Intelligence Agency (1894-2002), File Unit: ORE 53, NARA Record Group 263.

${ }^{18}$ Archives of Banco de España, Instituto Español de Moneda Extranjera [ABE-IEME], Secretaría, Box 133. (i.e., the archive of the Bank of Spain, Spanish Institute for Foreign Currency). 
power stations and electricity grid lines between 1956 and $1961 .{ }^{19}$ They predicted that the investment requirements would rise in future years due to growing consumer demand and the higher cost of $\mathrm{Kw}$ installed in nuclear versus thermal power stations.

There was the need to develop the test reactors, beginning in 1956 , for subsequent transfer to the private and public electricity sectors, and the deployment of the country's scientific knowledge base in the nuclear power industry. State funds were used to create - in the capital city, Madrid, next to the University and Cabinet Headquarters - a "technology park" to test early prototypes of electricity-producing nuclear reactors. ${ }^{20}$ The JEN also trained the country's first generations of nuclear experts and engineers at the Polytechnic Universities of Madrid, Barcelona and Bilbao, completing this training with apprenticeships in research centers abroad (mainly in the US, France, Germany and Italy). ${ }^{21}$ Private industry subsidized a laboratory in Bilbao, while the Barcelona Chamber of Commerce subsidized the experimental reactor for the School of Industrial Engineering. ${ }^{22}$ This joint effort was the key to the development of Spain's nuclear-based companies.

It was also the JEN, which, through its director, José $\mathrm{M}^{\mathrm{a}}$ Otero y Navascués, promoted an approximation between the administration, the energy entrepreneurs association, and the manufacturing goods sector. A physicist and naval engineer, he was closely connected to leading physicists in Europe and North America, and also played a crucial role in international relations of the JEN. ${ }^{23}$ July 1955 saw the creation of the Industrial Reactors Advisory Committee, known in Spain as the CADRI, a support agency for the JEN, which

\footnotetext{
${ }^{19}$ [ABE-IEME], Secretaría, Box 133.

${ }^{20}$ For the experimental Spanish reactors see A.Romero de Pablos, 'Poder político y poder tecnológico: el desarrollo nuclear español (1950-1975)', Revista CTS, nº 21, vol. 7, (2012) 141-162.

${ }^{21}$ Romero de Pablos and Sánchez-Ron, Energía nuclear en España.

${ }^{22} A B C$ (30 August1958) p. 25.

${ }^{23}$ C. Pérez Fernández-Turégano, José María Otero Navascués. Ciencia y Armada en la España del siglo XX. (Madrid 2012).
} 
brought together representatives from the government and the private electricity and industrial sector, to decide on a strategy. ${ }^{24}$ They all attended the First Geneva Conference, held in August of that year, which helped to forge the so-called Olaveaga Pact, signed in 1956, providing resounding proof of the interest of major electricity companies in the atomic business. Although the Spanish electricity market had a state-owned company (Endesa), electricity generation was left up to more than 20 private companies that divided the country geographically and configured the industry lobby, UNESA, since $1944 .^{25}$ Replicating their existing practices in the commercial production of hydraulic and thermal electricity, their aim was to split the market into north and south among the major electrical utilities to build nuclear power plants driving technological innovation in electric power generation. As a result, the northern electrical companies founded NUCLENOR for the deployment of nuclear power in northern Spain and the southern and central companies created CENUSA for the south, both in $1957 .{ }^{26}$ The task was not that simple, however. For the president of the INI at the time, the sheer scale of the nuclear project demanded the maximum presence of public companies, along with measures to prevent it from falling into the hands of a private monopoly. Right up to the end of his term in office at INI, Suanzes constantly struggled with the private companies. ${ }^{27}$ With the nuclear program of the JEN, the regime was also far from

\footnotetext{
${ }^{24}$ Blanco y Negro (10 January 1959) p.107.

${ }^{25}$ UNESA was created on the initiative of the private electrical utilities in 1944, under the name of Unidad Electrica, SA. Until 1979, it was also responsible for the operation of the national electricity grid system. UNESA controlled over $97 \%$ of the Spanish installed capacity throughout. See Muñoz and Serrano, 'La configuración del sector eléctrico', p.153.

${ }^{26}$ A. Romero De Pablos, 'Energía nuclear e industria en la España de mediados del siglo XX' in X. Roque and N. Herrán (eds) La física en la dictadura. Físicos, cultura y poder en España 1939-1975, (Barcelona 2012), p. 156. In parallel to the private companies' activity, the government created the Directorate General for Nuclear Energy for non-military uses in 1957. This was attached to the Ministry of Industry and was called upon to effect a deep transformation in the prevailing industrial order. $A B C$ (February 26, 1957), p.16.

${ }^{27}$ Suanzes, as president of INI, stated before Endesa's Board of Directors in June 1960 that the idea in the mind of Spanish private initiative was to get into nuclear energy as early as possible and present the state with a fait accompli by creating a few firms, with which they aimed to address the problem with an outlook that was provincial, regional or even parochial, and would maintain the same old monopolies and keep the nation's economy under the domination of the few. See A. Ballestero, Juan Antonio Suanzes, 1891-1977. La politica industrial de la posguerra (León 1993) pp. 320-323 and 329-330.
} 
monolithic. ${ }^{28}$ In 1957 , both, CENUSA and NUCLENOR, announced medium-term plans to build nuclear power stations.

This experimental stage took place between 1956 and 1962. The JEN's main project -by its size, technical complexity, and economic and financial significance- was the fine-tuning of three trials for the construction of experimental nuclear reactors, which included both fuel testing and power generation tests. While the first reactor was built in the US, the second and third were made in Spain, although the enriched fuel and graphite came from the US. ${ }^{29}$ Following the successful completion of this program in the early 1960s under US and Canadian guidance, similar programs were carried out in most IEA affiliated countries.

Large amounts of public funds were invested in JEN's facilities. Expenditure in constant pesetas reached its highest level between 1957 and the 1960s, a period during which atomic reactor testing took up approximately $60 \%$ of the agency's budget. ${ }^{30}$ The alliance with the electricity companies began to bear fruit as the companies agreed to bear some of the cost incurred in the experimental phase. Electricity utility managers were confident that the knowledge gained could be useful for them in the future. The uncertainty spread by Suanzes' attitude might have inspired a letter sent by the president of Hidroléctrica Española (one of the major electricity utilities companies), José $\mathrm{M}^{\mathrm{a}}$ de Oriol y Urquijo, to the director of the JEN, in April 1961. Having been appointed spokesman on behalf of CENUSA and NUCLENOR, Oriol demanded more certainty from the government given that "nuclear power stations come within the field of action of private electricity companies":

"If we are to lend our financial support to any nuclear-related activity in Spain, [...], we need to clarify our position in order to be ready to respond to our shareholders when they

\footnotetext{
${ }^{28}$ A. Gómez Mendoza, Electra y el Estado: la intervención pública en la industria eléctrica bajo el franquismo (Pamplona, 2007), p.530.

${ }^{29}$ Both Barca-Salom 'Dreams and needs' and Romero de Pablos, 'Poder político y poder tecnológico' list the main partners in the first project, and report the presence of UNESA on the JEN council.

${ }^{30}$ Own calculations based on data from Ordóñez and Sánchez-Ron, Nuclear Energy in Spain, p.200.
} 
question the motives behind the various investments that we have made. I do not rule out the possibility of NUCLENOR and CENUSA investing as much as 80 million pesetas, if we, as their participating companies, are able to tell our shareholders that the millions invested by each partnership will cover the initial investment towards the set-up fund to build the power station planned. [...] I know you will remind me of the Minister's clear and concise message, which [...] is what encouraged us to maintain our current position, but we need a guarantee that, just as there are conditions under which building concessions are granted for government-approved hydroelectric projects on Spanish rivers, we will be granted authorizations to build nuclear-fuelled power stations". ${ }^{31}$

This first stage was only a relative success, however, because it contained a basic flaw. The JEN had led the basic research, and had trained engineers in a technology that was to be used in the private sector. However, the next step, that of building of nuclear power stations for commercial use and their connection to the grid, remained a distant goal for a relatively poor country. Although scientists had played a key role in the foundation and basic development of this new industry, neither the public nor the private Spanish industrial structure of the late 1950s and early 1960s had the capacity to produce all of the nuclear and non-nuclear technology that the sector required. ${ }^{32}$ Among other reasons, the industrial policy of the autarky had proved ineffective for producing any type of high-tech capital goods, let alone those essential for nuclear development. ${ }^{33}$ The atomic race could not await the birth of the "Spanish reactor" (the DON project of the JEN), while the Americans, French, and Germans were almost ready to supply nuclear reactors on demand. To replicate the model of other European countries, Spain needed to make fundamental changes in its economic policy, particularly with respect to the industrial sector.

\footnotetext{
${ }^{31}$ ABE-IEME, Box. 133.

${ }^{32}$ In contrast, the Federal Republic of Germany and France succeeded thanks to their strong industrial capacity. South Korea also succeeded in replacing its foreign energy dependence with its own technology (see Thomas, The Realities of Nuclear Power, p. 144-47 and 197-99).

${ }^{33}$ A. Carreras and X. Tafunell. Historia Económica de la España Contemporánea (Madrid, 2004) p.308.
} 


\section{Forging the Spanish Nuclear Network (1962-1971)}

From 1959, the Spanish government applied the liberal economic package recommended by the IMF and the OEEC. For the country's nuclear strategy, this meant opening up to foreign capital (foreign companies and their knowhow) and a new boost to industrialization through indicative planning. Within this new context, the new Minister of Industry, Lopez-Bravo, decided in 1962 to authorize the construction of the first three nuclear power stations. All of them were built by the private sector, with only minor direct participation of the state in one of them: Valdellos I. All three would have imported reactors (two from the US and one from France), while the infrastructure engineering works and manufacture of the remaining components would gradually be handed over to domestic industries. Shortly afterwards, private companies grouped to form the Spanish Atomic Forum in order to defend their interests. The path towards Spain's nuclear enablement was still considered a matter of state but the private utilities and capital goods industry were to take the leading role. It was the fastest option for joining the atomic race. Yet this switch of direction, abandoning the plans for a Spanish reactor, was forced as much by the international scenario as by domestic issues.

By 1962, the US nuclear industry had begun large-scale commercial operations beyond its own borders. After a decade striving to set up a commercially viable nuclear energy production program, US federal institutions had chalked up more failures than successes. It had taken massive amounts of public funding to overcome the technical problems and get the experimental reactors producing electricity. Large-scale engineering problems in all of the prototypes remained to be solved. Only in the final years of the Eisenhower administration was it achieved. However, enthusiasm for the space race pushed nuclear energy to second place in the concerns of the new Democrat government and the economic viability of the program remained far beyond reach. Major US producers of non-nuclear capital goods 
expressed serious doubts as to its economic feasibility. Skeptics within the scientific community predicted its commercial use was still twenty years away, and warned about the safety risks. Only the government and technology pioneers in the private sector showed a decisive commitment to the nuclear business. Two issues were at stake: one was US prestige vis-à-vis the Soviet Union, and the other was the need to secure a return on invested capital. Thus, toward the end of 1962, the US Atomic Energy Commission (AEC) drafted a "Report to the President" with a twofold objective: first, to persuade the Kennedy government to double its funding for nuclear research and continue subsidizing private companies to build nuclear power plants; and, second, to create a favorable climate of public opinion toward developing the civil use of atomic energy. ${ }^{34}$

The announcement of the first commercial contract for a civil nuclear plant in the US, Oyster Creek, came in December 1962. General Electric [GE] and Westinghouse [WH] threw themselves into conquering both the domestic and the international market with a successful marketing campaign. For US companies, it was time to monetize the enormous effort they had been putting into developing the technology since the 1940s, with the support of the federal government and large private companies. Their sales pitch stated that atomic energy was close to being able to compete with conventional sources of electricity. It would soon be cheaper to build a nuclear power plant than a conventional one. ${ }^{35}$ In a frenzy of optimism for atomic technology, public decision-makers from many countries accepted these predictions and rushed to embrace the nuclear option. Western governments persuaded themselves that nuclear power plants were a good choice to guarantee cheap electricity, reduce their dependence on fossil fuels, and sustain medium-term economic development. This ideology

\footnotetext{
${ }^{34}$ Balog, Chain Reaction, p. 195-203.

${ }^{35}$ Ibid. Ignoring the fact that the commercial viability of the technology remained untested (see Cohn, 'The Political Economy of Nuclear Power')
} 
provided a perfect fit for the mixed economy and indicative planning of the era. Spain did not lag behind; it became one of the first customers in the GE and WH contract portfolios, along with West Germany, India, Japan, and Switzerland. ${ }^{36}$ As concluded in a foreign policy study commissioned by the US government:

'In certain cases there may be legitimate economic profit to be made from nuclear power [...] But it is surely at least equally as important that reactors, for better or worse, have become the visible symbol of technical progress and national attainment. Even more than a national airline, ownership of reactors is almost universally seen as the most direct route to stature in the world community. ${ }^{, 37}$

Local factors also counted in the private short cut to nuclearization in Spain. The Stabilization Plan of 1959 and the First Development Plan of 1963 entailed a new perspective on the energy needs of an accelerating economy. Developmentalist policymakers believed that nuclear power would strengthen the country's industrialization effort and involve the private sector in the process. Just a few months after the announcement of the construction of the first commercial plants in the US, the Spanish government authorized the first two nuclear plants of José Cabrera (Zorita) and Garoña. This addressed the doubts raised by Oriol 12 months before resolving in favor of the private energy sector.

Regulations passed a decade earlier required upgrading. The Nuclear Energy Act of April 1964 responded to both the international events and the reorientation of the country's economic policy. This act gave the rank of law to what until then had been a mere series of decrees. The act had two basic objectives. It began by redefining the powers of the Ministry of Industry with respect to the planning and coordination of energy policy, with atomic power as a strategic feature, and extended the functions of the JEN to include key aspects such as

\footnotetext{
${ }^{36}$ Thomas, The Realities of Nuclear Power, p. 9-11.

${ }^{37}$ I. Bupp and J.C. Derian, 'The Nuclear Power Industry" in Commission on the Organization of the Government for the Conduct of Foreign Policy ("Murphy Commission") vol. 1 Washington D.C. Government Printing Office, (Washington DC, 1975) p.94.
} 
"personnel training and technical specialization to prepare for the imminent [...] incorporation of nuclear energy to the domestic power supply". The new legislation sought to give greater flexibility to all parties in order to "further the peaceful application of nuclear energy", and thereby "contribute to the country's development." 38 This opened opportunities for private companies in the "new sectors required for the country's future development". It is symptomatic that the government should freely admit to "favoring the development of the nuclear industry by promising not to hold private capital fully responsible in the event of a nuclear accident". 39

Thus came about the Spanish version of the "nuclear iron triangle", ${ }^{40}$ a network pursuing the expansion of commercial nuclear-generated electricity by bringing together politicians, technicians (JEN scientists) and stakeholder groups (major electricity, building and civil engineering companies linked to the energy sector). The public sector moved in supporting the creation in 1967 of Ibérica de Estudios y Productos Nucleares, SA (Ibernuclear), in which it had $30 \%$ of the shares, while various private electricity companies held the remainder. ${ }^{41}$

The JEN Board concentrated most power in the decision-making process. Its members included representatives from the Ministries of Industry and Energy (two general directors), one each from the Ministries of Defense, Treasury, Interior, and Education, together with scientists, technicians and entrepreneurs "of renowned competence in the life of the nation". The instrument that gave formal recognition to this triple alliance, however, was the National Electricity Plan [Spanish acronym, PEN], which was designed along the lines set by the

\footnotetext{
${ }^{38}$ Law 25/1964 published in BOE (4 April 1964), see Caro, Historia nuclear española and also Energía Nuclear $\mathrm{n}^{\mathrm{o}} 44$ (1966).

${ }^{39}$ It happened in all nuclear countries, except that, in Spain, public discussion on the matter was impossible. In the US in 1964, despite the emergence of public criticism, the nuclear industry gained a 10-year extension on the 1957 law, which underestimated nuclear accident risk, cost and compensation (see Wood, Insuring Nuclear Power, pp. 5-11).

${ }^{40}$ Expression borrowed from Balog, Chain Reaction for the USA, p.62-66, institutional differences of a dictatorship notwithstanding.

${ }^{41}$ INI archives, Ibernuclear SA, Boxes 4322 and 6074.
} 
Energy Commission of the successive Development Plans. From 1964 to 1975, this Commission was the focal point for technocrats, scientists, and entrepreneurs to plan for energy demand and supply and set up investment plans for implementation by the economic ministries, mostly Industry and Public Works. The proposal for the 1964-67 period was, in fact, the embryonic form of the PEN of 1969, the key institutional instrument for collaborative decision-making between the public and private sector on matters relating to national energy policy.

The peculiar institutional structure of the dictatorship explains that the first PEN came to be designed under the dual auspices of UNESA and the Ministry of Industry. In what appeared to be an interchange of functions, the energy sector entrepreneurs' association made a planning proposal; the ministry's technical services units carried out the market research and network optimization studies; and, finally, the Directorate General for Energy approved the final PEN draft. ${ }^{42}$ Furthermore, the electric lobby performed a biennial review of the plan. As UNESA acknowledged in its annual report of 1971, implementation of the Third Economic Development Plan "is sure to have repercussions insofar as it will require us to speed up the growth of our sector and adopt legislative measures to ease the financial, fiscal, and technical pressures on the firms involved". ${ }^{43}$ In other words, the government arranged the necessary regulatory framework and scientific funding that enabled the major electricity companies to engage in the production of economically viable commercial nuclear energy. Overall, this institutional framework guaranteed Spain's ability to carry out uninterrupted and unhampered nuclear testing right up until 1970 . What eventually broke up this scheme were changes in the economic cycle and the political scene.

\footnotetext{
${ }^{42}$ Order dated 31st July 1969 approving the National Electricity Plan. BOE No 199 (20 August 1969).

${ }^{43}$ UNESA, Estadística Eléctrica (Madrid, 1971).
} 


\section{The Oil Crisis and the Nuclear Power Boom, 1972-1976}

The international literature has concluded that behind the nuclear optimism of the 1970s lay hidden risks that only came to light with the transition from experimental to commercial operations. First, planners had overestimated the country's electricity needs assuming that demand would increase steadily at a rate exceeding that of economic growth (which itself ran high at the peak of the Golden Age). Second, they had underestimated the costs and completion deadlines for the nuclear projects due to the claims and rivalry between the major North American companies -which virtually monopolized the international market for nuclear reactors up until 1974- and the entry of new European competitors. ${ }^{44}$ The final cost was always way over budget. Third, the belief that the transition from small to high capacity reactors (from $500 \mathrm{MGW}$ to over 1,000 MGW) could be achieved simply through economies of scale was shattered by a reality fraught with technical problems, the need to review safety standards, failure to meet deadlines and, ultimately, swollen funding costs. These three factors became blatantly apparent in 1973 with the demise of cheap fuel. The great paradox of the first oil crisis was that having initially hastened the nuclear programs all over the world it also brought to light its major weaknesses at once. In the case of Spain, this accumulation of factors extended even further the state's role in the nuclear power business, and involved the private sector up to the hilt.

Power demand in Spain had risen by an average of 7.8\% per year between 1960 and 1973 , while the GDP did so by only $5.5 \%{ }^{45}$ The government's optimistic forecasts in the first two

\footnotetext{
44 Until 1974, US firms had built two thirds of the world's nuclear reactors above 100 Gw. Adding those manufactured under GE and WH licences, the US share in reactors completed and under construction amounted to $84 \%$ at the time. Bupp and J.C. Derian, 'The Nuclear Power Industry', p.88.

${ }^{45}$ C. Sudrià, 'Un factor determinante: la energía', in J. Nadal, A. Carreras and C. Sudriá (comps.) La economíaa española en el siglo XX. Una perspectiva histórica. (Barcelona 1987) 313-364, p.340.
} 
Development Plans (1964-1971) only subsided in the third (1972-75). While the first plan set an annual growth target for electricity of $11.5 \%$, and the second went even further with a target of $13 \%$ per year between 1969 and 1985, the third plan reduced this to a more cautious $6.5 \%$. This overestimation played a crucial role both in private sector business strategy and in the commitments undertaken by public institutions. The planned output level required a corresponding increase in installed power (that is, in investment), and adaptation of the energy supply structure, which would prioritize nuclear production over hydraulic and thermal. While in 1971, with only two reactors plugged to the grid, nuclear represented 5\% of the electricity generated, the plan was for this to increase to $22 \%$ by 1981 and to $26 \%$ by 1990, thereby reducing the relative share of the other two sources [Table 2].

\section{[Table 2: Spanish electric power production trend forecast according to successive Energy Plans 1968- 1980 (in percentage terms)]}

As early as 1972, Spanish planners put forward the strategy that hinged nearly everything on nuclear development. Its two-fold objective was to reduce the balance of payments deficit due to oil imports, while promoting domestic technological and industrial research and development. With state support, the country paved the way for the consolidation of nuclear power companies. Spain's faith in the nuclear option rested on these two arguments. Each percentage point reduction in oil consumption would profit nuclear power producers and the country as a whole. The PEN implied a magnificent business opportunity for the electricity companies.

The nuclear power boom, however, was closely associated with three external shocks. The first two, the "temporary" suspension of the dollar-gold standard in August 1971, followed in October 1973 by an astronomical increase in oil prices, still resonate in public memory. Fluctuation in the exchange rate of the peseta against the dollar, favorable up to 1975 and 
acceptable up to 1980 , together with soaring oil prices, accelerated the government program for second- and third-generation nuclear power plants. The third external driving force behind the boom (and the least mentioned in the literature) was the marketing offensive, driven by the Nixon administration, to sell reactors and nuclear technology. By about 1970, the West German nuclear power industry had matured and was in a position to step up its competition with the US and France. Meanwhile, some developing economies -Brazil, Mexico, Argentina, Taiwan, South Korea, and the Philippines, among others- were also trying to jump on board the nuclear bandwagon. This forced the US -to date the world's leading nuclear exporter- to resort to a generous sales policy offering access to US public funding through credits granted by the Exim-Bank and major private banks, in an effort to forestall the collapse of its own nuclear sector. In 1975, H. Kissinger, US Secretary of State, in one of the many telegrams to the US Spanish Embassy related to atomic energy, stated:

'[...]With many proposed nuclear power projects in the US being deferred or cancelled, sales [to Spain] relating to these projects will help US manufacturers retain their specialized engineering and technical staffs and maintain production work forces'. ${ }^{46}$

This triple effect pushed Spain's nuclear network to embark on a project to reduce fossil fuels consumption by $20 \%$, replacing it with the same proportion of uranium fuel. On the last years of the dictatorship, between 1971 and 1976, the government pre-authorized no less than 18 new nuclear power plants (Figure 2), although almost 40 had been planned, and construction began on 15 of them. The energy sector entrepreneurs' association and the government were in full agreement in their diagnosis of the situation. UNESA made it quite clear in its 1975 review of the state plan that the purpose of the country's nuclear engagement was to guarantee energy supply, reduce the balance of payments deficit, and promote the rational use

\footnotetext{
${ }^{46}$ NARA Archives Document Numbers: 1974MADRID01553; 1975STATE074005; 1975STATE229036; 1975STATE 186005
} 
of energy. It described nuclear energy as an essential resource and the only medium-term option for meeting increasing power demand. Its internal documentation actually went much further than the Ministry of Industry's official energy forecasts. The major electricity companies were planning for $54 \%$ of Spain's electricity production to be nuclear in 1985 , i.e., twice the government's estimate (Table 3). ${ }^{47}$ Meanwhile, confidence rested on public subsidies and privileged access to credit, for the capital goods industry to be able to achieve the capacity to reduce Spain's dependence on technology imports. ${ }^{48}$

\section{[Table 3: UNESA Electricity Production Forecast (in percentage terms)]}

The government continued to play a key role in ensuring the scientific basis, by involving both the JEN and, more especially, some INI companies. The public holding undertook the challenge to produce the nuclear fuels and capital goods required, trusting that this would reduce outlays on an essential input, namely, uranium, and increase the domestic share in new equipment and mechanical components for thermal and nuclear power plants. All three Development Plans included stepping up uranium mining prospecting and research, and the trial of commercial fast reactors, given that the dominant technology used enriched uranium (the US monopolized its market until 1974, when the USSR entered a market that would become increasingly competitive). From 1971, Spain redoubled its efforts to produce irradiated fuels through ENUSA, the national uranium company. The state committed to a capital investment in ENUSA slightly higher than the overall cost of a nuclear power plant. ${ }^{49}$

\footnotetext{
${ }^{47}$ UNESA, Estadistica Eléctrica (1975).

48 The Development Plans and the so-called Concerted Action financed second- and third-generation nuclear power plant promoting companies through tax benefits and access to official credit. See F. Braña and M. Buesa Gastos fiscales y política de industrialización en España, 1964-1977. Ministerio de Economía y Hacienda. (Madrid 1983).

${ }^{49}$ In 1972, the investment required for each of the seven power plants planned for 1975 was estimated at 10,000 million pesetas ( $\$ 175$ million), with 11,000 million pesetas ( $\$ 192$ million) for the enriched fuel cycle. See Presidencia del Gobierno, III Plan de desarrollo (Madrid 1972) p. 202 and 203. Amounts in dollars by us.
} 
Later, in 1972, the INI founded a new partnership (Equipos Nucleares, SA), which brought together several domestic and foreign private companies and the three main electricity companies, to manufacture reactor vessel components, steam generators and circuits for nuclear power plants. The US and Germany would provide the technological backup that would enable the Spanish firm to supply the nuclear plants still under construction. ${ }^{50}$

Upon these foundations, the government and the electricity entrepreneurs' association threw themselves into achieving the target set by the 1975 PEN. Between mid-1975 and the first democratic elections, held in June 1977, key nuclear program investment decisions were made. Meanwhile, the Spanish economy's developmentalist growth cycle had almost run its course, and the country was entering a period of recession marked by rising prices, steep industrial decline, falling power demand [Figure 1], a number of bank failures, and increasing inflation. Under these conditions, the energy legacy inherited from the dictatorship entailed a very costly mortgage.

\section{[Figure 1: Projected vs actual electricity consumption and GDP growth rates (1964-1980)]}

\section{Democracy, the financial bailout, and the nuclear moratorium (1977-85)}

A mere glance at Figure 1 suffices to show that the electric power output figures for 1980 were well off-target. While the results for hydraulic and thermal power production were quite satisfactory, nuclear-fuelled power production had barely achieved $11 \%$ of its projected output (Table 4). It had proved simply impossible to bring to conclusion those nuclear power plants that had been authorized or were already in construction and connect them to the grid according to plan. Meanwhile, investment forged ahead amid spiraling financial costs. This

\footnotetext{
${ }^{50}$ Namely, Westinghouse, General Electric and KW. See Múñoz and Serrano, 'La configuración del sector eléctrico', p. 222 and 233.
} 
state of affairs was partly due to technical and economic issues but also inextricably linked to political factors.

\section{[Table 4: Projected and actual electricity output, 1969-1980 (in MW)]}

Starting with the technical and economic reasons, the developmentalist estimates were possibly unrealistic for the industrial and financial potential and for capabilities of an economy such as that of Spain in 1975. This miscalculation took place at a time of drastic change in the macroeconomic framework of the Western world. Additionally, the nuclear development plans of the 1950s and 1960s were under complete review as the nuclear issue started to provoke growing social resonance even before any serious accidents had occurred. All of this had the effect of hitting the nuclear program's economic efficiency. Both direct and indirect costs increased, which multiplied even further following the incident at Three Mile Island [TMI] (Pennsylvania) in March 1979.

For Spain, this was the worst-case scenario: one that would shake to the core the finances of the main companies that had embarked on the nuclear adventure. Prior authorizations and construction works had been negotiated between 1972 and 1978 in a highly stable environment that was favorable to the peseta exchange rate, although the bank rate had already started to rise. Between 1979 and 1985, however, the value of the US dollar against the peseta had multiplied by 2.5 (Figure 2). Contracts with US, French, and German multinationals for the purchase of nuclear equipment had been denominated in foreign currencies and with a period of grace allowing deferment of the first payment to the early 1980s. Furthermore, the volume of investment committed had triggered increasing recourse to 
international banks, and the resulting external debt had to be guaranteed, in one way or another, by the state. ${ }^{51}$

The situation was summed with great clarity in an Exim-Bank report of 1983, describing Spain as "the single largest borrower" among a dozen countries that, together, had contracted 61 loans for the construction of nuclear power plants. Spain's debt exposure had grown, especially in the last two years, to 965 million dollars, i.e., $22 \%$ of the nuclear credits granted by Exim. The report went on to say that it was simply impossible for utilities in countries such as Korea, the Philippines, Spain, and Yugoslavia to raise, in the private market, the $\$ 500$ million or more required for a single nuclear plant. ${ }^{52}$ Some level of public debt was therefore inevitable.

\section{[Figure 2: Spanish Nuclear Program: forecasts, outcomes, and Peseta-US Dollar} exchange rate (1960-1985)]

Over a very short period of time, a policy of investment in fixed assets had driven the major electricity companies into heavy debt. Their ratio of fixed to current assets had risen from $35 \%$ in the mid- 1970 s to no less than $52 \%$ by 1983 . The extent of this phenomenon is even easier to appreciate in GDP terms, because while the current assets of the Spanish electricity system (in constant currency) were worth $3.5 \%$ of GDP in 1975 , they had reached $11 \%$ by 1980 , and $20 \%$ by 1983 , their net fixed assets having multiplied by 6.2 in less than a decade. ${ }^{53}$ These companies were also rapidly heading into serious business management problems due to the deteriorating global economic environment.

As in most countries with operating nuclear plants, the financial situation grew more serious as new, stricter safety regulations (the so-called TMI effect) made it harder for bidding

\footnotetext{
${ }^{51}$ J. Aranceta 'Estructura financiera del sector eléctrico', Economía Industrial, no 237, (1984).

${ }_{52}^{52}$ Export Import Bank of the United States Archives [Exim archives], Box H128, Folder 705.

${ }^{53}$ Own calculations based on data M. Espita, 'Resultados económicos y financieros del sector eléctrico, 19621983', Economía Industrial, 243, (1985) pp. 91-109.
} 
companies to meet project deadlines. Any delay in the engineering work, or in mechanical, electrical equipment, or component assembly had dire consequences. The engineering firms were doubtless aware of the risk involved in failing to meet deadlines. Let us not forget, at this point, that efforts to maximize Spanish firms' participation in the building of nuclear plants were still at the trial stage, and the country still had much to learn in order to raise the percentage of contracts to domestic firms above the $40 \%$ mark.

Table 5 depicts five possible scenarios in the building process for a nuclear plant in Spain in the late 1970s and early 1980s, with the following givens: 1) in a project of this caliber, it took a minimum of seven or eight years for the plant to become commercially operational, and, therefore, the monetary updating of the direct and indirect costs needed to be staggered; and 2) the price of money could vary in the medium to long term, thus affecting financial costs. Any delay not only entailed higher overall costs, it also had a very negative impact on the cost structure: in the worst-case scenario-that is, a project taking twelve years to complete, with growing interest rates and inflation driving up costs - the budget shortfall would have to be met by debt financing. Interest payments could account for as much as $47 \%$ of the total investment. This was even stated by the president of the Hidroelectrica Española, which had a share in three plants (Almaraz, Cofrentes and Valdecaballeros), speaking before the 1984 General Annual Board Meeting: "electricity installations call for long-term programming, in the region of ten or twelve years", therefore, "the material investment in a nuclear power plant in Spain accounts for $50 \%$ of the total investment; the remaining $50 \%$ is taken up by the interest incurred during construction, and by successive updates". 54

[Table 5: Impact of money prices and project completion time on the cost structure for a nuclear power plant in Spain, 1978-1990 (in percentage terms)]

\footnotetext{
${ }^{54}$ Hidroeléctrica Española Shareholders Board (30 May 1984), in Economía Industrial, 1984, № 237.
} 
The level of financial risk involved in the nuclear power boom called for political measures at a time when Spain was immersed in its transition to democracy. This made a singular background for the strategic decisions that had to be made. In energy policy terms, the transition from an authoritarian regime to a free one meant institutional change and new tools for public intervention. From the start, democracy led to public debate and, from 1977 onwards, the government Energy Plan was reviewed, discussed, and approved in a multi-party parliamentary setting. The public voice could also be heard, especially in regions where building nuclear power plants had already commenced, and press coverage brought lobbying by stakeholder groups into the public eye. Between 1977 and 1983, public opinion on the nuclear issue ranged from firm support for a program along the original basic lines, and appeals for a nuclear moratorium and reassessment of the situation.

Consensus on the basic appraisal was reached in the first major democratic macroeconomic policy agreement, in October 1977. The Moncloa Pacts established the need for a new energy plan to address the balance of payments deficit due to oil imports and speed up the development of "domestic resources". 55 When the never-to-be-approved energy plan was submitted to the lower house between the autumn of 1978 and the summer of 1979 , oil imports accounted for over 70\% of the Spanish balance of payments deficit. This vulnerability prompted the government of the Central Democratic Union party (UCD) to present an energy plan aimed at reducing consumption growth rates, diversifying and ensuring energy supplies and promoting domestic resources to the full. The seven plants under construction were to be completed, and a further three projected plants were to be authorized (the remainder would have to be put on hold until at least 1987). In other words,

\footnotetext{
55 "Finally, maximum possible use of domestic technology for nuclear power needs, while both imports of nuclear equipment and technology transfers will take place under government supervision and coordination". Boletín Oficial de Cortes [BOC], number 26, November 3, 1977.
} 
the essence of the pre-1975 agreement was to be upheld, although planned investment would be adjusted to the new economic and power production scenario.

There was actually very little room for maneuver. A statement by the spokesman for the PSOE (Spanish socialist workers' party) in the lower house declared that Spain had already been nuclearized, that the Spanish nuclear program was not under discussion, and that the only thing to be done was to review it. ${ }^{56}$ In line with the PCE (the Spanish communist party), the socialists proposed to nationalize not the nuclear power plants, but the high voltage grid, and advanced the idea of a nuclear stoppage by calling for an expert committee to decide what to do with the seven plants under construction, ban the construction of the three pending authorization, and freeze plans for the eight remaining. The discrepancy over how many power plants to construct before 1987 was a domestic reflection of the global dynamic. Following the TMI and Harrisburg incidents, industrialized countries had toned down their nuclear frenzy. International reports were now warning that nuclear power ceases to be a cheap source of energy once the costs of radioactive waste management and the dismantling of defunct power plants were included. ${ }^{57}$ This was truer still given that Spain's institutional response to both these issues was still pending. ${ }^{58}$ Off the record, however, the energy sector entrepreneurs' association continued its campaign in favor of atomic energy, with warnings of the risk of a return to underdevelopment. The second oil crisis, which erupted in late 1979, strengthened the government's resolve to reduce the country's dependence on foreign energy supplies by maintaining plans for the construction of 10 plants, and incorporating a new form

\footnotetext{
${ }^{56}$ Javier Solana, a prominent socialist member of parliament, added that "the country has been nuclearized in an anti-democratic and chaotic fashion, in a context devoid [...] of debate, that is, with no rational plan of action, and with very specific private interests in mind rather than the general good". It was described by El Pais newspaper as a "fait àccompli policy". El País $(27$ April 1977).

${ }^{57}$ BOC N ${ }^{\circ} 129$.

${ }^{58}$ Safety legislation, at least, had been put in place. In March 1981, the Nuclear Safety Council (CSN) was set up to, among other things, pass on to Congress the controversial six-monthly reports on the civil uses of the sector. Consejo de Seguridad Nuclear (CSN) 1982-1986. Informe al Congreso de los Diputados y al Senado. (Madrid 1982) p. 9.
} 
of power generated by nuclear fusion. ${ }^{59}$ Meanwhile, the economic crisis was deepening, and the ETA contributed to the debate with terrorist attacks including the assassination of the two chief engineers at the Lemóniz plant and other assaults on power company interests. ${ }^{60}$

The energy policy of the new socialist administration, which came into power in December 1982, included a complete review of the PEN, and implementation of the discussed but not approved 1978/1979 plan. With respect to the electricity sector, analysts insisted on the need for institutional reform and avoidance of the over-investment that had accompanied previous planning. By February 1983, this amounted to 600,000 million pesetas ( $\$ 4.1$ billion) that could be used in other projects. Possibly the most radical institutional change introduced to improve productivity was the nationalization of the high voltage grid. ${ }^{61}$ The oversupply of the nuclear sector became apparent, particularly in relation to estimated growth in power demand in a depressed economy. After a period of consultation and negotiation with the power companies, in the autumn of 1983, the government announced the nuclear moratorium. ${ }^{62}$ It responded to the double imbalance of excess of borrowing and of power pants. ${ }^{63}$ It was a

\footnotetext{
${ }^{59}$ Minister of Industry briefing. Boletín Oficial de Cortes [BOC], No 026 (December 17, 1980). Consejo de Seguridad Nuclear (CSN) 1982-1986. Informe al Congreso.

${ }^{60} \mathrm{~J}$. Garrués, 'Las estrategias productivas'.

${ }^{61}$ J.Garrués and S. López, 'Red Eléctrica de España, S.A.: Instrument of regulation and liberalization of the Spanish electricity market (1994-2004)', Renewable and Sustainable Energy Reviews, 13, (2009) 2061-2069.

A contemporary analysis in J.Fabra and J.I. Bartolomé. 'Sector eléctrico: reflexiones sobre aspectos conocidos' Economia Industrial, 243 (1985) 23-36. At the same time, further action was taken to reform the JEN -to promote its role in technological and industrial development- and the CSN, and legislation on radioactive waste management and cost allocation was introduced.

${ }^{62}$ El Pais, 15/9/1983; $A B C, 18 / 10 / 1983$, p.29. The moratorium was announced on the order of Ministry of Industry and Energy of October 14, 1983, implementing the rule on economic matters in the Royal Decree 2660/1983, of October 13, which provided in paragraph 2 creation of a fund implemented through an account at UNESA operated by the Department of Energy, to address the financial and real obligations arising from ongoing investments in those facilities whose future had not been considered in the forecast again National Energy Plan. The latter was not approved until 1984, and so were the provisions that established how the costs of the moratorium would translate on to electricity tariffs. It would take 4 more years to establish the recognized costs of the moratorium (see BOE-A-1988-4778).

${ }^{63}$ This formed the essence of the strategy by the Ministry of Power and Industry see Cortes Generales: Congreso de los Diputados n⿳亠丷厂 12, 'Acta de la Comisión de Industria, Obras Públicas y Servicios' 22/02/1983, available at: http://www.congreso.es/portal/page/portal/Congreso/Congreso/Publicaciones/. The power companies' view was expressed at the Unión Eléctrica-Fenosa General Assembly, held in May 1984: “... the PEN [of 1983] addresses, in a realistic fashion, the financial adjustment of the sector, made necessary due to the major investment that has been exacted from the sector by the Administration in the past". From Economía Industrial, 1984, №237.
} 
"temporary" stoppage that would cost the power companies an estimated 500,000 million pesetas ( $\$ 3.5$ billion) which the government planned to pay back over the following 25 years by increasing electricity prices; that is, at consumers' and tax payers' expense. By then, UNESA and the Spanish Atomic Forum had accepted the moratorium as inevitable. They approved of the compensation mechanisms but expressed concern regarding the impact on auxiliary industries. ${ }^{64}$ In this regard, the Ministry of Industry took a continuity approach by supporting the nuclear component and equipment manufacturers. ${ }^{65}$ Yet, at the same time it waged a campaign to clean up the electricity sector by restoring the balance between companies' borrowing levels and their income-generating capacity.

Three decades after the Spanish government's decision to pause and reshape the country's developmentalist nuclear power plan, controversy lingers. Some judge it to have been a mistake with very little technical justification. Others see it as one of the greatest economic disasters to have befallen Spain since the transition to democracy. Still others view it as the government's response to the financial breakdown suffered by the major power companies that had embarked on a nuclear program that overstretched the country's capabilities. ${ }^{66}$ In any event, by 1984, Spain had achieved much greater nuclear power capacity than could be expected with its level of development, and not far behind that of countries such as West Germany or Japan.

\footnotetext{
${ }^{64}$ The Spanish Confederation of Business Organisations (CEOE) and the Confederation of the Metal sector also expressed their fears for the nuclear manufacturing network. El Pais (15 October 1983; November 6, 1983; December 6, 1983; December 17, 1983). An appraisal of the power company situation, in E. Ontiveros and F.J. Valero, 'El programa financiero del sector eléctrico', Economía Industrial, $\mathrm{n}^{\circ} 243$ 81985) 45-52. An overview of the sector in Foro Nuclear, La industria nuclear española. (Madrid 2011).

${ }^{65}$ Economía Industrial, $1985 \mathrm{~N}^{\circ} 230$, pp.142-143.

${ }^{66}$ Against the moratorium see R. Centeno, 'El impacto del cierre de centrales nucleares' XVIII Observatorio Económico. Conferencias FAES (Madrid, July 20, 2009); In defense of the moratorium see C. Narbona and J. Ortega, La energía después de Fukushima, (Madrid 2012); J. Sánchez Vázquez,'Los discursos de legitimación de la industria nuclear española'. Revista Paz y Conflictos, nº 2. 2009.
} 


\section{Some conclusions}

The context within which certain decisions were made regarding the main energy sources for electricity production differs greatly across counties. Beyond defining the energy requirements and limiting the financially feasible options, the institutional setting also defines who took (or influenced) the decision-making process and how. In these pages, we established that one of the main differences between Spain and the rest of Western Europe is precisely that the former was a dictatorship and the later democracies. That defined how decisions were made: in the Spanish case without any checks or balances. In fact, Spain was the only dictatorship among the early nuclear adopters. The dictatorship made some things more difficult (e.g., access to external technology and funds, worsened human capital of the country, and the strong control and disruption of markets). However, at the same time we argue that one of the explanations for why nuclear development outpaced economic growth in Spain is the institutional setting: a dictatorship combined with a lobbying electricity sector that influenced without opposition the decisions made by officials in the government and regulatory agencies. However, those were insufficient conditions: the collaboration of the technological leaders, especially the US, was needed.

Although the initial steps of the nuclear program in Spain were mostly due to the personal commitment of Otero Navascués through the JEN, its role slowly diluted as the government allowed the private sector to take the lead after 1962. The specific regulatory conditions of the Spanish electricity market encouraged the belief that there was money to be made from investing in nuclear power plants. This was so even in the final stage of the autarchy, and particularly at the height of the import substitution industrialization era, when not even the US was quite sure of the wisdom of leaving nuclear investment in private hands. The definitive boost to the strategy was provided by the developmentalist economic and industrial policy, 
backing the private companies plans. This required the collaboration of all of the economic ministries (the Ministries of Industry and Commerce, the Treasury, the Bank of Spain), a whole body of favorable legislation, which will add to helping form training personnel and expert creation that the JEN had done for over a decade.

Spanish nuclear deployment came about as a response to both internal and external forces. On the domestic front, the priority, according to developmentalist logic, was to address the energy dependence problem and accelerate industrial growth. On the foreign front, the US nuclear industry, with government support, and Exim funding, thought that the time was ripe to conquer the international market and collect a return on the gargantuan effort the US had put into making its nuclear strategy technically and economically viable. Spain was to be one of its best customers. Other drivers of the investment frenzy included a threatened increase in the price of foreign energy supplies, and a flood of cheap credit in the international capital market, which enabled Spain's nuclear power boom of the early 1970s. With state backing, the electricity companies launched a highly ambitious program that included auxiliary industries. By the mid-1970s, however, all of the apparent advantages had vanished. Two oil crises, stagflation, and dwindling supplies of cheap money caught the power companies with power plant construction and grid connection in full sway. These financial problems were surfacing just as Spain's new democratic government was reviewing the institutional nuclear power framework built by the dictatorship, and countries around the world were reassessing the challenges involved in the nuclear paradigm. 


\section{Figure 1: Projected vs actual electricity consumption and GDP growth rates} (1964-1980)

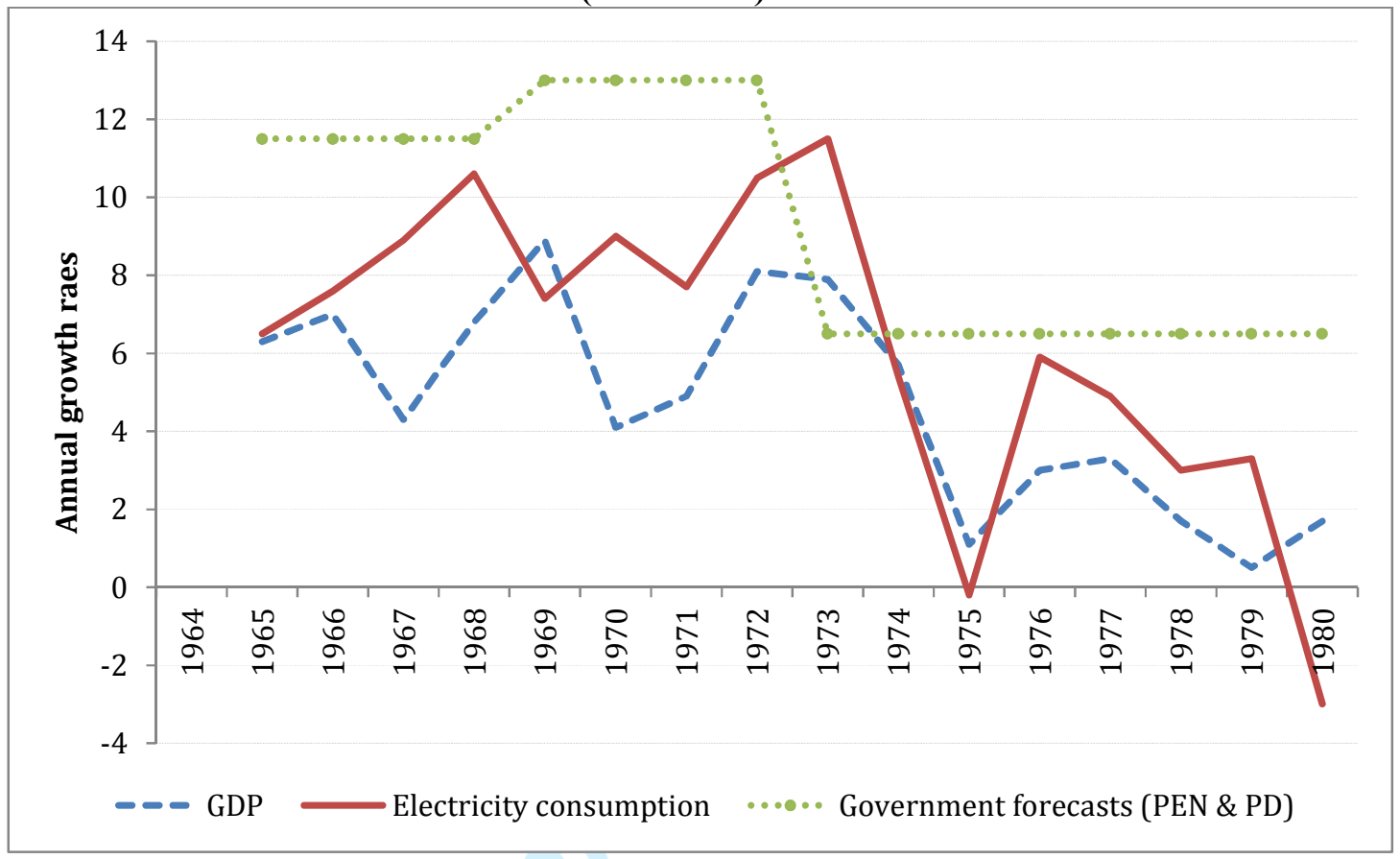

Sources: Elaborated from data in J. Ma García Alonso, La energía en España (1983), Presidencia del Gobierno, [I ]Plan de Desarrollo Económico y Social (Madrid 1963: pp. 199-209); Presidencia del Gobierno, [II] Plan de Desarrollo Económico y Social. Anex (Madrid, 1968: pp. 84-85), and Memoria sobre la ejecución del III Plan de Desarrollo (Presidencia del Gobierno, Madrid, 1975: pp. 374-379). Annual growth rates of GDP from A. Carreras and X. Tafunell. Historia Económica de la España Contemporánea (Madrid, 2004: pp. 474-489) 
Figure 2: Spanish Nuclear Program: forecasts, outcomes, and Peseta-U.S. Dollar exchange rate (1960-1985)

Sources: Own elaboration from data on the capacity of projected, authorised, suspended, and grid connected nuclear plants. Romero de Pablos and Sánchez Ron, Energía nuclear en España, (pp.276) report on data for 33 reactors. We added the project of Irta that appears in BOE 5/12/1966 No290 and in $A B C$ 20/3/1973, (p.37). They do not offer the beginning of works for most plants. We have gathered such information for Almaraz I\&II, Cofrentes, Trillo I\&II, Valdecaballeros I\&II, Valdellós II from CSN, Informe al Congreso 1981 (p.108). The projects without authorization are assumed to be abandoned in 1978 except for those where activity can be found after that date such Regodola, Sayago, and Escatrón I which are considered just projects despite having building activity (see M.d.M. Rubio and J. De la Torre (2014), ¿Nucleares No?. Available at http://www.aehe.net/xicongreso/pdfs/s6_rubio_delatorre.pdf). Date of connection to grid taken from UNESA Memoria Anual (years 1968 to 1988). Exchange rate pta/\$ from Carreras and. Tafunell Estadísticas históricas.pp.705-706 
Table 1: World figures for atomic energy production and nuclear intensity, 1971

\begin{tabular}{lccccc}
\hline Country & $\begin{array}{c}\text { Nuclear } \\
\text { generation } \\
(\mathbf{G w h})\end{array}$ & $\begin{array}{c}\text { Population } \\
\mathbf{( 0 0 0 )}\end{array}$ & $\begin{array}{c}\text { Nuclear per } \\
\mathbf{( 0 0 0} \text { habs) }\end{array}$ & $\begin{array}{c}\text { GDPpc } \\
(\mathbf{1 9 9 5} \mathbf{)})\end{array}$ & $\begin{array}{c}\text { Nuclear per } \\
\mathbf{0 0 0 \$}\end{array}$ \\
\hline UK & 7.18 & 55,907 & 128.41 & 10,941 & 11.74 \\
Canada & 1.11 & 22,026 & 50.49 & 12,562 & 4.02 \\
France & 2.43 & 51,285 & 47.44 & 12,110 & 3.92 \\
USA & 10.57 & 207,661 & 50.89 & 15,304 & 3.33 \\
Switzerland & 0.36 & 6,343 & 57.15 & 17,381 & 3.29 \\
Spain & 0.66 & 34,195 & 19.23 & 6,618 & 2.91 \\
Japan & 2.08 & 104,345 & 19.98 & 10,040 & 1.99 \\
Germany & 1.62 & 78,355 & 20.67 & 11,077 & 1.87 \\
Italy & 0.88 & 54,006 & 16.24 & 9,839 & 1.65 \\
India & 0.31 & 541,000 & 0.57 & 856 & 0.67 \\
Netherlands & 0.11 & 13.194 & 8.00 & 12,319 & 0.65 \\
\hline
\end{tabular}

Sources and notes: own elaboration from International Energy Agency/OECD World energy balances: Beyond 2020 (Vienna/Paris 2013)f or primary nuclear production. A. Maddison, Historical Statistics of the World Economy: 1-2008 AD (Paris, 2008) for population and income (GDP) per capita. The table shows all countries with commercial nuclear capability, except the USSR for which there are no historic IEA/OECD data.

Table 2: Spanish Electric Power production trend forecast according to successive Energy Plans 1968- 1980 (in percentage terms)

\begin{tabular}{lccccc}
\hline & $\mathrm{A}$ & $\mathrm{B}$ & $\mathrm{C}$ & & $\mathrm{D}$ \\
\hline & & & & & \\
& II Dev't Plan (1968) & PEN 1969 & PEN 1981 & $\%$ & Multiplier \\
for 1971 & for 1981 & for 1990 & (C-A) & $1971 / 1980$ \\
Hydraulic & 54.3 & 43.1 & 39.0 & -15.3 & 1.7 \\
Coal-burning & 40.6 & 13.3 & 25.6 & -15.0 & 3.3 \\
Oil-burning & & 21.8 & 9.3 & -12.5 & 1.2 \\
Nuclear & 5.1 & 21.8 & 26.2 & 21.1 & 20.9 \\
Total & 100.0 & 100.0 & 100.0 & & 2.6 \\
\hline
\end{tabular}

Source: Memoria sobre la ejecución del III Plan de Desarrollo (Presidencia del Gobierno, Madrid, 1975).

Plan Eléctrico Nacional (BOE, nº 199, Madrid, 1969) and García Alonso, "La energía en España" (1983: 3-5).

Table 3: UNESA Electricity Production Forecast (in percentage terms)

\begin{tabular}{cccc} 
& 1976 & 1980 & 1985 \\
\hline Hydraulic & 33 & 28 & 22 \\
Coal fuelled & 24 & 28 & 18 \\
Oil fuelled & 36 & 14 & 6 \\
Nuclear & 7 & 30 & 54 \\
Total & 100 & 100 & 100 \\
\hline
\end{tabular}

Source: UNESA (1975: p. 41). 
Table 4: Projected and actual electricity output, 1969-1980 (in MW).

\begin{tabular}{lcccc}
\hline \multicolumn{4}{c}{ First PEN } & 1980 \\
& MW & & Diff. \\
projected & Actual MW & MW & \% Accomplished \\
Hydraulic & 16.8 & 13.2 & -3.62 & 78.5 \\
Coal-fuelled & 5.2 & 6.4 & 1.17 & 122.5 \\
Oil-fuelled & 8.5 & 8.2 & -0.34 & 96.0 \\
Nuclear & 8.5 & 1.0 & -7.51 & 11.6 \\
Total & 39.0 & 28.7 & -10.3 & 73.6 \\
\hline Source: First and Second Economic and Social Development Plans (1963), pp. 199-209 and (1968), pp. \\
75-86) and Memoria (1975), pp. 373-379). BOE $\mathrm{N}^{\circ}$ 199, dated 20 August 1969, and $\mathrm{N}^{\circ}$ 40 dated 15 \\
February 1975.
\end{tabular}

Table 5: Impact of money prices and project completion time on the cost structure for a nuclear power plant in Spain, 1978-1990 (in percentage terms)

\begin{tabular}{lccccc}
\hline & A & B.1 & B.2 & B.3 & B.4 \\
\hline Assumptions & & & & & \\
$\quad \begin{array}{l}\text { Completion time } \\
\text { Staggered cost }\end{array}$ & 7 years & 8 years & 12 years & 12 years & 12 years \\
$\begin{array}{l}\text { impact } \\
\text { Price of money }\end{array}$ & & 6.40 & 6.40 & 8 & 10 \\
\hline Share of total costs: & & 9 & 9 & 10 & 12 \\
$\quad$ Building costs & 72 & 55 & 41 & 36 & 29 \\
Staggered investment & & 16 & 20 & 23 & 24 \\
Accum. interest & 28 & 29 & 39 & 42 & 47 \\
Total & 100 & 100 & 100 & 100 & 100 \\
\hline
\end{tabular}

Sources and notes: Column A. Author's own estimates based on Múñoz and Serrano, 'La configuración del sector eléctrico', pp. 218-19. The staggered cost is already included in the physical cost.

Columns B1-B4: Scenarios considered by J. Rojas, 'Costes de generación de energía eléctrica', Economía Industrial, No237 (1984), pp. 128-31. 